\title{
KEJELASAN SASARAN ANGGARAN DAN SPIP TERHADAP AKUNTANBILITAS KINERJA INSTANSI DIMODERASI PARTISIPASI PENYUSUN
}

\author{
Mardiana1, Supami Wahyu Setiyowati ${ }^{2}$ \\ Universitas Islam Negeri Maulana Malik Ibrahim Malang1 \\ Jl. Gajayana No 50 Malang \\ Universitas PGRI Kanjuruhan Malang2 \\ Jl. S. Supriadi No.48 Malang \\ e-mail: mardiana@uin-malang.ac.id1,$\underline{\text { setiyo@unikama.ac.id² }}$
}

\begin{abstract}
The purpose of this study was to examine and explain the clarity of budget targets, and the internal control system on performance accountability in OPD Malang City in moderation of budgetary participation. This study uses quantitative research methods. Population of 34 Regional Apparatus Organizations in Malang City. The data analysis technique used multiple regression analysis. The results showed the clarity of budget targets, and the internal control system had an effect on performance accountability in OPD Malang City. A clear budget and according to organizational goals increases the accountability of the performance of government agencies. The implementation of an internal control system in each activity increases the accountability of the performance of government agencies. Participation in budgeting moderates the relationship between the clarity of budget targets and the internal control system that affects performance accountability. Participation in budgeting is very important for the preparation of a government budget in accordance with organizational goals. With participation in budgeting, the clarity of budget targets and the internal control system has increased and has an impact on increasing the accountability of government performance.
\end{abstract}

Keywords: : Clarity of targets, internal control systems, participation in budgeting, and accountability

\section{Abstrak}

Tujuan riset ini yaitu menguji serta menjelaskan kejelasan sasaran anggaran, serta sistem pengendalian internal pada akuntabilitas kinerja pada OPD Kota Malang di moderasi partisipasi penyusunan anggaran. Riset ini menggunakan metode penelitian kuantitatif .Populasi sebesar 34 Organisasi Perangkat Daerah pada Kota Malang. Teknik analis data menggunakan multiple regresi analysis Hasil riset menjelakan kejelasan sasaran anggaran, serta SPI berpengaruh pada akuntabilitas kinerja pada OPD Kota Malang. Anggaran yang jelas dan sesuai tujuan organisasi meningkatkan akuntanbilitas kinerja instansi pemerintah. Implementasi sistem pengendalian internal pada setiap kegiatan meningkatkan akuntanbilitas kinerja instansi pemerintah. Partisipasi penyusunan anggaran memoderasi hubungan kejelasan sasaran anggaran dan sistem pengendalian internal berpengaruh pada akuntabilitas kinerja. Partisipasi penyusunan anggaran sangat penting untuk penyusunan anggaran pemerintah yang sesuai dengan tujuan organisasi. Dengan adanya partisipasi penyusunan anggaran kejelasan sasaran anggaran serta SPIP meningkat serta berdampak pada peningkatan akuntanbilitas kinerja pemerintah.

Kata Kunci: Kejelasan sasaran, sistem pengendalian internal, partisipasi penyusunan anggaran, dan akuntanbilitas

\section{PENDAHULUAN}

Akuntabilitas kinerja merupakan sebuah bentuk pertanggungjawaban atas keberhasilan atau kegagalan atas terlaksanakannya tugas serta fungsi instansi pemerintah berdasarkan pada sasaran yang sudah direncanakan melalui suatu sistem 
Mardiana dan Supami Wahyu Setiyowati : Kejelasan Sasaran Anggaran Dan Spip Terhadap Akuntanbilitas Kinerja Instansi Dimoderasi Partisipasi Penyusun

pertanggungjawaban dengan berkala (PP No 29 tahun 2014). Pembentukan sistem pertanggungjawaban ini tidak lepas dari tujuan utama pemerintah yaitu menciptakan pemerintahan yang bersih dan berwibawa atau yang sering disebutkan dengan good governance.

Kinerja ialah gambaran terkait tingkat tercapainya pelaksanaan kegiatan maupun program dari wujudnya sasaran, visi, serta misi organisasi yang ada pada perancanaan strategi suatu organisasi. Pengukuran kinerja ialah bagian penting bagi pemerintah untuk mewujudkan akuntabilitas. Pengukuran kinerja dilakukannya indikator kinerja kegiatan berupa input, output, serta outcome yang digunakannya dalam pengukuran ekonomis, efisiensi, serta efektivitas dalam tercapainya sasaran (Mahsun 2013). Sistem akuntabilitas kinerja instansi pemerintah ialah diterapkannya manajemen kinerja terkait sektor publik yang sejalan serta berhubungan dengan diterapkannya reformasi birokrasi, yang memiliki orientasi pada tercapainya outcome serta upaya dalam didapatkannya hasil lebih baik. (Endrayani 2014). Jelasnya anggaran berdampak pada pegawai dalam penyusunan anggaran terkait sasaran yang tercapai, jadi aparat akan mempunyai informasi cukup dalam diprediksinya masa depan secara tepat. Adanya sasaran anggaran yang jelas bisa membantu aparat pelaksanaan anggaran untuk tercapainya target realisasi anggaran yang ditetapkannya sebelumnya (Hidayat 2015). Sistem pengendalian internal berpengaruh pada akuntanbilitas. SPI meliputi struktur organisasi, metode serta ukuran yang terkoordinasikan dalam terjaganya keutuhan organisasi, mendorong supaya timbulnya suatu keefektifan secara efisiensi serta dapat terpahaminya kebijakan manajemen serta pengecekan ketelitian data akuntansi (Hutama danYudianto 2019).

Untuk menjaga peningkatan akuntabilitas kinerja pemerintah wajib diterapkannya ABK, maka diperlukan peningkatan partisipasi penyusunan anggaran. Partisipasi penyusunan anggaran ialah terlibatnya semua pegawai pada instansi untuk dilakukannya kegiatan pada tercapainya sasaran yang ditetapkan pada organisasi tersebut. Dengan terlibatnya pegawai bisa mendorong pegawai serta kepala bagian dalam mempertanggungjawabkan masing-masing tugas yang diemban. Partisipasi anggaran ialah gambaran proses individual dengan terlibatnya penyusunan anggaran serta mempunyai pengaruh pada target anggaran. Anggaran berbasis kinerja menuntut adanya hasil optimal maupun output yang teralokasikan, jadi nantinya tiap pengeluaran harus berorientasi maupun bersikap ekonomis, efektif serta efisien pada saat pelaksanaan serta tercapainya output. Partisipasi dalam peningkatan kinerja pemerintah diberikannya kesempatan bahwa bawahan dalam ikut memberikan partisipasi memengaruhi proses tersusunnya anggaran. (Anwar dan Sumiati 2014).

Sesuai Kepala Badan Pengelolaan Keuangan dan Aset Daerah Kota Malang Sapto Prapto Santoso Secara total, penyerapan anggaran mencapai 44,37\% dari target Rp2,067 triliun.Sedangkan realisasi pendapatan, sampai akhir Agustus 2018 mencapai 66,98\% dari target penerimaan sebesar Rp1,962 triliun. Dari penerimaan sebesar itu, sumbangan PAD mencapai Rp486,330 miliar, sedangkan sampai Agustus sudah terealisasi Rp363,352 miliar atau 74,71\%, dana perimbangan Rp1,142 triliun, realisasinya Rp816,812 miliar atau 71,48\%, lain-lan pendapatan daerah yang sah, terealisasi Rp133,977 miliar dari target Rp332,988 miliar atau 40,23\%.Sampai menjelang akhir September, penyerapannya baru mencapai $40 \%$ dari target penyerapan anggaran belanja langsung sebesar Rp1,142 triliun 
sampai akhir 2018.Penyebab agak melambatnya penyerapan anggaran belanja langsung karena gonjang-gonjing politik di Malang, yakni kasus diperiksanya sebagian besar anggota DPRD dan beberapa eksekutif oleh KPK terkait dengan pelaksanaan P-APBD 2015. Karena itulah, OPD menjadi agak ketakutan dalam melakukan belanja langsung. Penyebab lainnya, karena adanya Perpres No. 16 tahun 2018 tentang Pengadaan Barang/Jasa Pemerintah.Dalam Perpres tersebut, proses lelang dini atau lelang sebelum APBD ditetapkan tidak diperbolehkan. Namun aturan yang baru, juga dapat mempercepat penyerapan anggaran. Dalam aturan baru, isi dari APBD tidak perlu lagi dikonsultasikan ke Pemprov, termasuk yang perlu dikonsultasikan terkait Rencana Kebijakan Pemerintah Daerah.Penyerapan APBD 2019 akan lebih bagus bila dibandingkan 2018. Dengan pelaksanaan kegiatan yang baik, maka diperkirakan pada Januari sudah bisa dilakukan tender, paling lama pada Februari. Pemkot Malang memberlakukan sanksi bagi organisasi perangkat daerah (OPD) yang tidak tertib dalam penyerapan APBD 2019 untuk belanja langsung. (bisnis,com).

Menurut (Nurhalimah 2013), menemukan hasil partisipasi penyusunan anggaran memberikan pengaruh dengan Kinerja Pemerintah Daerah. Penelitian (Tolley, Ridwan, and Kasim 2017) Pengendalian Internal, Kejelasan Sasaran Anggaran serta Pergantian Kepala SKPD secara bersamaan mempengaruhi Akuntabilitas Kinerja SKPD Provinsi Sumatera Tahun 2017 (Indriasih 2014). Penelitian ini sangat penting dilakukan karena partisipasi penyusun anggaran sangat menentukan jelasnya anggaran serta implementasi SPI sehingga tercipta akuntanbilitas kinerja instansi pemerintah. Kebaruan penelitian ini adalah dengan menambahkan variabel moderasi partisipasi penyusun anggaran yang akan memperkuat hubungan kejelasan sasaran dan SPIP untuk menciptakan akuntanbilitas kinerja pemerintah.

\section{KAJIAN PUSTAKA}

\section{Teori agensi}

Teori ekonomi terkait keagenan memberikan prediksi serta kejelasan perilaku pihak yang terkait dengan adanya suatu entitas. Dalam hukum, seorang agen ialah orang yang mempekerjakan untuk terwakilinya kepentingan pemilik dengan pihak lainnya. Teori ekonomi terkait agen ditunjang dengan konsep hukum keagenan (Astika 2011).

\section{Teori Stewardship}

Teori stewardship mendeskripsikan keterkaitan yang kuat dengan kinerja organisasi serta suksesnya organisasi, jadi fungsi atas organisasi tersebut bisa maksimal. Asumsi penting stewardship ialah steward memiliki pandangan lurus tujuan organisasi sesuai dengan tujuan prinsipal. Steward berperilaku sesuai dengan kesepakatan serta kepentingan bersama.Apabila terjadi perbedaan kepentingan antara kedua pihak, steward akan berusaha bekerja sama dari pada melakukan penentangan (Jefry 2018).

\section{Akuntabilitas}

Sistem akuntabilitas kinerja instansi pemerintah (SAKIP) ialah penerapan manajemen kinerja terkait sektor publik yang berjalan dengan diterapkannya reformasi birokrasi yang mempunyai orientasi tercapainya outcome serta upaya didapatkannya output yang baik. Hal ini berarti sistem akuntabilitas kinerja pemerintah menerapkan manajemen kinerja untuk mencapai tujuan yang telah ditetapkan. 


\section{Kejelasan Sasaran Anggaran}

Kejelasan sasaran anggaran berdampak terhadap aparat terkait penyusunan anggaran yang sesuai sasaran yang ingin dicapai instansi pemerintah. Aparat bisa mempunyai informasi yang cukup dalam diprediksinya masa depan dengan tepat, sasaran anggaran PemDa harus ternyatakan secara jelas, spesifik serta bisa dimengerti mereka yang memiliki tanggung jawab untuk pelaksanaannya (Hidayat 2015). Kejelasan sasaran anggaran akan menciptakan akuntanbilitas.

\section{Sistem Pengendalian Internal}

SPI berpengaruh pada akuntanbilitas. SPIP meliputi struktur organisasi, metode serta ukuran yang terkoordinasi untuk menjaga utuhnya organisasinya, faktor pendorong terciptanya efektivitas secara efisiensi dapat dipahaminya kebijakan manajemen serta pengecekan ketelitian data akuntansi (Hutama and Yudianto 2019). SPIP menciptakan akan menciptakan akuntanbilitas dalam organisasi

\section{Partisipasi Anggaran}

Partisipasi anggaran ialah proses yang mendeskripsikan individu terlibat pada tersusunnya anggaran serta mempunyai pengaruh pada target anggaran. Anggaran berbasis kinerja dituntut adanya output yang optimal maupun pengeluaran yang teralokasikan. Jadi nantinya tiap pengeluaran harus memberikan orientasi serta bersikap ekonomis, efektif serta efisien pada saat tercapainya suatu output tersebut. (Anwar and Sumiati 2014).

\section{Kerangka konseptual}

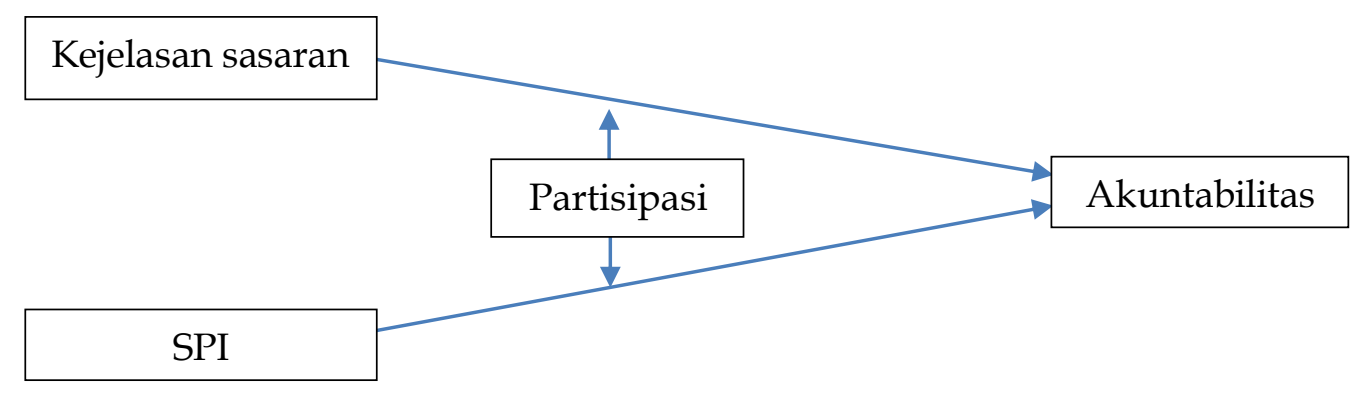

Gambar 1. Kerangka konseptual

\section{HIPOTESIS}

\section{Dampak Kejelasan Sasaran Anggaran terhadap Akuntabilitas Kinerja Instansi Pemerintah.}

Kejelasan sasaran anggaran tercakup misi anggaran serta kejelasan yang sesuai dengan sasaran yang tercapai pada instansi pemerintah serta bisa di pahami oleh siapapun yang bertanggungjawab pada pencapaian itu, maka akuntabilitas akan terwujud. Kejelasan sasaran anggaran mendeskripsikan seberapa jauh sasaran anggaran ternyatakan secara baik, jelas, serta bisa dipahami oleh mereka yang memberikan tanggung jawab atas pencapaian tersebut. Adanya sasaran anggaran yang jelas, maka bisa memudahkan dalam dipertanggungjawabkan berhasilnya maupun gagalnya pelaksanaan organisasi dalam tercapainya tujuan atas sasaran yang sudah diterapkan sebelumnya (Indriasih 2014). 
Mardiana dan Supami Wahyu Setiyowati : Kejelasan Sasaran Anggaran Dan Spip Terhadap Akuntanbilitas Kinerja Instansi Dimoderasi Partisipasi Penyusun

Maka hipotesisnya ialah:

$\mathrm{H}_{1}$ : Diduga kejelasan sasaran anggaran berpengaruh terhadap akuntanbilitas kinerja instansi pemerintah

Dampak Sistem Pengendalian Intern terhadap Akuntabilitas Kinerja Instansi Pemerintah

Menurut (Faishol 2016), SPIP ialah proses yang pokok pada aktifitas yang dilakukan pemimpin serta seluruh pegawai dalam diberikannya rasa yakin memadai atas tercapainnya tujuan organisasi melalui aktivitas yang efektif serta efisien, keandalan informasi keuangan, pengamanan aset negara serta ketaatan pada regulasi perundangan. Penelitian oleh (Fitrawati, Kahar, and Ikbal 2017), menjelaskan SPI berpengaruh positif serta signifikan pada akuntabilitas kinerja instansi pemerintah daerah. SPIP yang baik menunjukkan organisasi bisa menciptakan kegiatan yang baik, yang nantinya bisa memberikan keyakinan bagi organisasi bahwa kegiatan yang berjalan sudah berjalan sesuai ukuran yang diterapkan secara efektif serta efisien. Maka hipotesisnya ialah:

$\mathrm{H}_{2}$ : Diduga Sistem Pengendalian Internal berpengaruh terhadap Akuntabilitas Kinerja Instansi Pemerintah

Dampak kejelasan sasaran anggaran terhadap akuntanbilitas kinerja pemerintah dimoderasi partisipasi penyusunan anggaran

Jelasnya sasaran anggaran ialah seberapa jauh tujuan anggaran diterapkan dengan jelas serta spesifik dengan tujuan supaya anggaran tersebut bisa dipahami orang yang bertanggung jawab atas tercapainya sasaran anggaran tersebut. (Hidayat 2015). Terdapat 3 hal yakni partisipasi tersusunnya anggaran bisa dijadikan penyebab pimpinan maupun bawahan bisa berkomitmen pada organisasi disebabkan adanya tanggung jawab yang timbul. Kedua, partisipasi penyusunan anggaran mempunyai persamaan dikarenakan pimpinan maupun bawahan akan terlibat sebagai tersusunnya anggaran. Ketiga, partisipasi penyusunan anggaran membuat atasan bisa mengetahui informasi dari bawahan terkait pekerjaan. Hipotesisnya ialah:

$\mathrm{H}_{3}$ : Diduga kejelalasan sasaran anggaran berpengaruh terhadap akuntanbilitas kinerja pemerintah dimoderasi partisipasi penyusunan anggaran

Dampak sistem pengendalian intern terhadap akuntanbilitas kinerja pemerintah dimoderasi partisipasi penyusunan anggaran

SPIP ialah proses integral yang dilaksanakan secara menerus serta efektif efisien oleh pemimpin yang terancang untuk memberikan keyakinan atas tercapainya tujuan organisasi serta terselenggaranya secara menyeluruh pada lingkungan pemerintah pusat serta pemerintah daerah. (Nurhalimah 2013), menjelaskan pada Pemerintah Daerah, makna partisipasi ialah terlibatnya SKPD dalam (APBD). Hipotesisnya ialah:

$\mathrm{H}_{4}$ : Diduga sistem pengendalian intern berpengaruh terhadap akuntanbilitas kinerja pemerintah dimoderasi partisipasi penyusunan anggaran

\section{METODE}

Jenis penelitian yakni penelitian kuantitatif. Data kuantitatif penelitian berupa data jumlah pegawai serta jawaban kuesioner yang didapatkan dari responden. Jenis data yang digunakannya data primer. Sumber data primer pada riset didapatkan secara langsung dari Organisasi Perangkat Daerah Kota Malang melalui kuesioner yang tersebar kepada 
Mardiana dan Supami Wahyu Setiyowati : Kejelasan Sasaran Anggaran Dan Spip Terhadap Akuntanbilitas Kinerja Instansi Dimoderasi Partisipasi Penyusun

pegawai di instansi pemerintahan tersebut. Populasi riset ialah Organisasi Perangkat Daerah (OPD) pada Kota Malang. Jadi populasinya ialah 34 OPD yang terdiri dari 19 Dinas, 6 Badan, 5 Kecamatan, 1 Satpol PP, 1 Inspektorat, 1 Sekretariat Daerah dan 1 Sekretariat DPRD pada Kota Malang di Sub. Bagian Perencanaan \& Keuangan yakni Kepala Sub. Bagian Perencanaan \& Keuangan dan Staf. Sampel yang digunakan pada penelitian ini ialah sejumlah 146 sampel dari 19 Dinas, 6 Badan, 5 Kecamatan, 1 Satpol PP, 1 Inspektorat, 1 Sekretariat Daerah dan 1 Sekretariat DPRD pada Kota Malang di Sub. Bagian Perencanaan \& Keuangan yaitu Kepala Sub. Bagian Perencanaan \& Keuangan serta Staf.

\section{HASIL DAN PEMBAHASAN}

Hasi Uji asumsi klasik

Hasil uji normalitas

Hasil normalitas Kolmogorov Smirnov

Tabel 1. Hasil uji normalitas

\begin{tabular}{lcl}
\hline Variabel & Hasil uji asymp sig. & Keterangan \\
\hline KSA terhadap AKP & 0,060 & Normal \\
SPI terhadap AKP & 0,113 & Normal \\
KSA*PPA terhadap AKP & 0,617 & Normal \\
SPI*PPA terhadap AKP & 0,787 & Normal \\
\hline
\end{tabular}

Sumber: Hasil Analisis (2020)

Hasil uji normalitas menunjukkan asymp sig $>5 \%$, ini berarti data berdistribusi normal.

Tabel 2. Hasil multikolonieritas

\begin{tabular}{lll}
\hline Variabel & VVif & Keterangan \\
\hline KSA terhadap AKP & 1,422 & Terbebas multikolonieritas \\
SPI terhadap AKP & 1,428 & Terbebas multikolonieritas \\
KSA*PPA terhadap AKP & 2,878 & Terbebas multikolonieritas \\
SPI*PPA terhadap AKP & 2,878 & Terbebas multikolonieritas \\
\hline
\end{tabular}

Sumber: Hasil Analisis (2020)

Pada tabel terlihat VIF ada pada bawah 10 serta dengan tolerence diatas 0,5, maka model regresi bermakna terbebas Multikolinearitas

Tabel 3. Hasil Uji Heteroskedastisitas

\begin{tabular}{lll}
\hline Variabel & Sig $(2$ tailed $)$ & Keterangan \\
\hline KSA terhadap AKP & 0,973 & Terbebas heteroskedastisitas \\
SPI terhadap AKP & 0,558 & Terbebas heteroskedastisitas \\
KSA*PPA terhadap AKP & 0,667 & Terbebas heteroskedastisitas \\
SPI*PPA terhadap AKP & 0,779 & Terbebas heteroskedastisitas \\
\hline
\end{tabular}

Sumber: Hasil Analisis (2020) 
Hasil Uji menjelaskan nilai abs sig $>0,05$ halini menunjukkan model terbebas heterokedstisitas.

Tabel 4. Hasil uji multiple regresi analysis

\begin{tabular}{llll}
\hline Variabe & coefisen & ssig & keterangan \\
\hline $\begin{array}{l}\text { KSA terhadap AKP } \\
\text { SPI terhadap AKP }\end{array}$ & 0,144 & 0,023 & berpengaruh \\
berpengaruh
\end{tabular}

Sumber: Hasil Analisis (2020)

\section{HASIL DAN PEMBAHASAN}

\section{Dampak kejelasan sasaran anggaran terhadap akuntanbilitas kinerja pemerintah}

Hasil menunjukan makin tinggi tingkatan tepatnya anggaran maka akuntabilitas kinerja instansi makin naik. Sasaran anggaran dijelaskan secara pokok, jelas serta bisa dipahami oleh mereka yang bertanggungjawab terkait pencapainnya. Adanya sasaran anggaran tepat, bisa memudahkan dalam dipertangggungjawabkan berhasilnya maupun gagalnya terlaksanakannya tugas organisasi dalam tercapainya tujuan serta sasaran yang ditetapkan sebelumnya.

Hasil ini mendukung teori keagenan (agency theory) terkait pihak principal dilakukannya pengawasan pada kinerja pihak agen melalui laporan kinerja serta keuangan yang tersampaikan oleh pihak manajemen. teori agensi (agency theory), pegawai pemerintah sebagai agent mempunyai kewajiban dalam diberikannya tanggungjawab, penyajian, pelaporan, serta pengungkapan segala aktivitas serta kegiatan yang dijadikan tanggungjawab dengan pihak pemberian amanah (principal) yang mempunyai hak serta wewenang dalam meminta tanggungjawab tersebut.

Penelitian sejalan dengan (Anjarwati 2012), kejelasan anggaran berpengaruh pada akuntabilitas kinerja pemerintah. Sejalan dengan (Hutama and Yudianto 2019), menunjukkan hasil analisis menjelaskan jelasnya sasaran anggaran memiliki pengaruh signifikan serta positif pada akuntabilitas kinerja, diperkuat (Manullang and Abdullah 2019), menjelaskan kejelasan sasaran anggaran berpengaruh positif, makin terperinci tujuan serta sasaran yang ditetapkan, maka semakin baik akuntabilitas kinerja bagi (SKPD).

\section{Dampak sistem pengendalian intern terhadap akuntanbilitas kinerja pemerintah}

Pemerintah Kota Malang telah menerapkan SPI karena hasil penelitian menunjukkan SPIP secara signifikan berpengaruh pada akuntabilitas kinerja. Lingkungan pengendalian ialah salah satu penunjang dalam berjalannya tata kelola pemerintahan yang baik dikarenakan pengendalian internal sangat membantu efektivitas dan efisiensi dalam mengawasi kinerja instasi pemerintah. Pengendalian internal juga membantu pemerintah dalam melaksanakan standar operasional prosedur yang memudahkan 
kinerja pegawai untuk mengurangi resiko dalam pelaksanaan tugas dan tanggung jawabnya, serta menghalangi apabila ada penyalahgunaan jabatan atau kekuasaan. Karena pengendalian internal mendorong agar pegawai memiliki integritas, kompetensi, komunikasi yang efektif, dan kerjasama yang baik, pembagian tugas dan tanggungjawab serta patuhnya pada regulasi perundang-undangan yang berlaku. Sistem pengendalian internal tidak hanya bersifat administrasi saja, akan tetapi sistem yang mengatur sikap pegawai sehingga implementasi sistem pengendalian internal tergantung pada kesadaran serta komitmen pegawai, pimpinan dan pejabat instansi pemerintah. Oleh karena itu, untuk meningkatkan kinerja sistem pengendalian internal, maka pemerintah Kota Malang secara berkesinambungan melakukan sosialisasi peraturan pemerintah, pelatihan serta pendidikan terhadap pegawai perencanaan dan keuangan daerah.

Penelitian sejalan dengan teori stewardship yang mendeskripsikan keterkaitan yang kuat antara kinerja organisasi serta suksesnya organisasi, maka fungsi dari organisasi tersebut akan maksimal. Asumsi terpenting dari stewardship adalah steward meluruskan tujuan organisasi sesuai dengan tujuan principal.

Penelitian sejalan dengan (Fitrawati et al. 2017), SPIP berpengaruh positif serta signifikan pada akuntabilitas kinerja instansi pemerintah daerah, diperkuat hasil (Manullang and Abdullah 2019), menjelaskan pengendalian internal berpengaruh signifikan serta memiliki pengaruh yang positif secara parsial pada akuntabilitas kinerja. Hal ini bermakna, semakin baik pengendalian internal yang dilaksanakan oleh SKPD, maka makin baik akuntabilitas kinerja yang dihasilkan.

\section{Dampak kejelasan sasaran anggaran terhadap akuntanbilitas kinerja pemerintah dimoderasi partisipasi penyusunan anggaran.}

Kejelasan anggaran diikuti partisipasi penyusunan anggaran akan memberikan peningkatan akuntanbilitas kinerja pemerintah. Makin jelas serta terpahaminya anggaran akan memberikan kontribusi partisipasi penyusunan anggaran makin baik. Partisipasi atas tersusunnya anggaran bisa meningkatkan kinerja pemerintah, adanya partisipasi memberikan peluang kepada bawahan untuk berpartisipasi memengaruhi proses tersusunnya anggaran.

Atas penjelasan tersebut, peran kejelasan sasaran anggaran memengaruhi akuntabilitas kinerja dengan dibantu partisipasi seluruh pegawai maupun individu yang turut berpartisipasi atas tersusunnya anggaran. Terdapat sasaran anggaran yang jelas, maka bisa memudahkan melakukan tanggung jawab atas berhasilnya maupun gagalnya tugas organisasi pada tercapainya tujuan atas sasaran yang diterapkan.

\section{Dampak sistem pengendalian internal terhadap akuntanbilitas kinerja pemerintah di} moderasi partisipasi penyusunan anggaran

Komponen pokok pengendalian internal ialah pengawasan yang berlanjut serta berkala. (Hutama and Yudianto 2019). SPIP baik pada organisasi akan menciptakan seluruh sistem kegiatan yang baik, jadi nantinya bisa diberikannya keyakinan bagi organisasi, jika aktivitas yang terlaksana sudah sejalan sesuai ukuran yang diterapkan secara efektif. Oleh karena itu, dalam meningkatkan kinerja SPI sekiranya pemerintah Kota Malang secara berkesinambungan melakukan sosialisasi peraturan pemerintah, pelatihan dan pendidikan terhadap pegawai perencanaan dan keuangan daerah.

Sesuai penjelasan tersebut adanya sistem pengendalian internal maka suatu 
kinerja pemerintah akan dapat dipertanggungjawabkan atau bersifat akuntabel. Adanya peran partisipasi penyusunan anggaran dapat meningkatkan sistem pengendalian internal yang baik, dimana dengan adanya suatu pastisipasi oleh individu-individu yang terlibat pada penyusunan anggaran maka mereka secara tidak langsung telah menjalankan kebijakan manajemen yang sesuai dengan sistem pengendalian internal. Dengan demikian adanya partisipasi penyusunan anggaran oleh individu-individu terkait bisa meningkatkan sistem pengendalian internal terkait dengan kebiajakan manajemen dan akan mendorong terciptanya suatu efektivitas secara efisiensi. Hasil ini juga didukung dengan suatu berita yakni Kota Malang memberlakukan sanksi bagi organisasi perangkat daerah (OPD) yang tidak tertib dalam penyerapan APBD 2019 untuk belanja langsung.(bisnis,com), makna tersebut bahwa sistem pengendalian internal telah diperketat dan dengan hal tersebut dapat meningkatkan akuntabilitas kinerja keuangan.

\section{KESIMPULAN}

Hasil simpulan menjelaskan makin tingginya tingkat jelasnya sasaran anggaran maka akuntabilitas kinerja instansi naik. Sasaran anggaran bermakna secara spesifik, jelas serta bisa dipahami oleh mereka yang melaksanakan tanggung jawab dalam pencapaiannya. Peran kejelasan sasaran anggaran berpengaruh pada akuntabilitas kinerja. SPIP mempengaruhi akuntabilitas kinerja keuangan, adanya lingkungan pengendalian ialah salah satu penunjang pokok dalam terlaksanakannya serta terkelolanya pemerintahan yang baik karena pengendalian internal sangat membantu efektivitas dan efisiensi dalam mengawasi kinerja instasi pemerintah. Pengendalian internal juga membantu pemerintah dalam melaksanakan standar operasional prosedur yang memudahkan kinerja pegawai untuk mengurangi resiko dalam pelaksanaan tugas dan tanggung jawabnya, serta menghalangi apabila ada penyalahgunaan jabatan atau kekuasaan. Hasil berikutnya partisipasi penyususnan anggaran memoderasi hubungan kejelasan sasaran anggaran pada akuntabilitas kinerja keuanagan. Peran jelasnya sasaran anggaran memengaruhi akuntabilitas kinerja dengan dibantu adanya partisipasi seluruh pegawai ataupun individu-individu yang turut berpartisipasi dalam penyusuanan anggaran. Partisipasi penyususnan anggaran memoderasi hubungan sistem pengendalian internal pada akuntabilitas kinerja keuanagan. Adanya peran partisipasi penyusunan anggaran dapat meningkatkan sistem pengendalian internal yang baik, dimana dengan adanya suatu pastisipasi oleh individu-individu yang terlibat pada penyusunan anggaran maka mereka secara tidak langsung telah menjalankan kebijakan manajemen yang sesuai dengan sistem pengendalian internal.

\section{Saran}

Elemen yang perlu dipertimbangkan ketika meningkatkan kinerja pemerintah adalah partisipasi tersusunnya anggaran, jelasnya sasaran anggaran, serta sistem pengendalian internal, di mana ketiga faktor tersebut sangat penting untuk mengelola anggaran daerah, karena partisipasi individu-individu di samping organisasi pemerintah. Dalam hal ini, pemerintah daerah kota Malang harus meningkatkan ketiga faktor tersebut dengan menjadi lebih terlibat dalam urusan pemerintahan dan dengan menaruh minat pada pemerintah.

Terkait bagi peneliti berikutnya bisa menambahkan variabel moderasi lain seperti 
Mardiana dan Supami Wahyu Setiyowati : Kejelasan Sasaran Anggaran Dan Spip Terhadap Akuntanbilitas Kinerja Instansi Dimoderasi Partisipasi Penyusun

komitmen organisasi di mana komitmen organisasi sangat penting untuk mengelola anggaran daerah, karena komitmen organisasi adalah partisipasi karyawan di samping organisasi pemerintah dan bagi peneliti berikutnya bisa menambahkan OPD pada kabupaten agar bisa membandingkan.

\section{Batasan Penelitian}

Terkait batasan penelitian pada artikel ini, maka batasannya yang pertama ialah hanya melakukan penelitian pada Organisasi Perangkat Daerah (OPD) pada Kota Malang. Jadi populasi pada riset ini ialah 34 OPD yang terdiri dari 19 Dinas, 6 Badan, 5 Kecamatan, 1 Satpol PP, 1 Inspektorat, 1 Sekretariat Daerah dan 1 Sekretariat DPRD pada Kota Malang di Sub. Bagian Perencanaan \& Keuangan yaitu Kepala Sub. Bagian Perencanaan \& Keuangan dan Staf. Sampel yang digunakan pada riset ialah sejumlah 146 sampel dari 19 Dinas, 6 Badan, 5 Kecamatan, 1 Satpol PP, 1 Inspektorat, 1 Sekretariat Daerah dan 1 Sekretariat DPRD pada Kota Malang di Sub. Bagian Perencanaan \& Keuangan yaitu Kepala Sub. Bagian Perencanaan \& Keuangan dan Staf. Batasan kedua yakni hanya terkait variabel yang diteliti saja.

\section{DAFTAR PUSTAKA}

Anjarwati, Mei. 2012. "Pengaruh Kejelasan Sasaran Anggaran, Pengendalian Akuntansi, Dan Sistem Pelaporan Terhadap Akuntabilitas Kinerja Instansi Pemerintah." Accounting Analysis Journal.

Anwar, Suhardi, and Sumiati. 2014. "Pengaruh Partisipasi Penyusunan Anggaran Terhadap Kinerja Aparat Pemerintah Daerah (Studi Kasus Pada Dinas Pendapatan, Pengelolaan Keuangan Aset Daerah Kota Palopo)." Jurnal Manajemen ISSN 2339-1510 Vol. 01 No.

Astika. 2011. Konsep-Konsep Dasar Akuntansi Keuangan. Bali: Udayana University Press.

Endrayani, Dkk. 2014. "Pengaruh Penerapan Anggaran Berbasis Kinerja Terhadap Akuntabilitas Kinerja Instansi Pemerintah (Studi Kasus Pada Dinas Kehutanan UPT KPH Bali Tengah Kota Singaraja)." E-Journal S1 Ak Universitas Pendidikan Ganesha Jurusan Akuntansi Program S1 Volume 2,

Faishol, Ahmad. 2016. "Pengaruh Sistem Pegendalian Intern Terhadap Kualitas Laporan Keuangan." Jurnal Penelitian Ekonomi Dan Akuntansi Vol. 1, No.

Fitrawati, Abdul Kahar, and Ikbal. 2017. “Moutong), Pengaruh Kejelasan Sasaran Anggaran Dan Sistem Pengendalian Intern Terhadap Akuntabilitas Kinerja Instansi Pemerintah (Survei Pada Satuan Kerja Perangkat Daerah (SKPD) Kabupaten Parigi." E-Journal Katalogis Volume 5 N:177-84.

Hidayat, Rahmad. 2015. “Pengaruh Pengelolaan Keuangan Daerah Dan Sistem Akuntansi Keuangan Daerah Terhadap Kinerja Pemerintah Daerah." Jurnal Fakultas Ekonomi Universitas Negeri Padang.

Hutama, Rifqi, and Ivan Yudianto. 2019. “The Influence of Budget Participation, Budget Goals Clarity and Internal Control Systems Implementation on Local Government Performance." Journal of Accounting Auditing and Business Vol. 2, No. 
Mardiana dan Supami Wahyu Setiyowati : Kejelasan Sasaran Anggaran Dan Spip Terhadap Akuntanbilitas Kinerja Instansi Dimoderasi Partisipasi Penyusun

Indriasih. 2014. "He Effect of Government Apparatus Competence and the Effectiveness of Government Internal Control Toward the Quality of Financial Reporting in Local Goverment." Research Journal of Finance and Accounting Vol. 5, No.

Jefry, Riny. 2018. "Teori Stewardship Dan Good Governance." Jurnal Riset Edisi XXVI UNIBOS Vol. 04, N.

Mahsun, Mohamad. 2013. Pengukuran Kinerja Sektor Publik. Yogyakarta: BPFE.

Manullang, Surya Benediktus, and Syukriy Abdullah. 2019. "Pengaruh Pengendalian Internal, Kejelasan Sasaran Anggaran, Dan Pergantian Kepala SKPD Terhadap Akuntabilitas Kinerja." Jurnal Ilmiah Mahasiswa Ekonomi Akuntansi (JIMEKA) Vol. 4, No:62-73.

Nurhalimah. 2013. "Pengaruh Partisipasi Penyusunan Anggaran Dan Kejelasan Sasaran Anggaran Terhadap Kinerja Aparatur Perangkat Daerah Di Pemerintah Aceh." Jurnal Teknik Sipil ISSN 2302-0164 27-36.

Tolley, Sukma, Ridwan, and Yunus Kasim. 2017. "Pengaruh Sistem Pengendalian Internal Pemerintah Terhadap Kinerja Satuan Kerja Perangkat Daerah Kabupaten SIGI." E Jurnal Volume 5 N:179-90.

Peraturan Perundang-undangan:

Peraturan Pemerintah No.60 Tahun 2008 Tentang System Pengendalian Internal.

Peraturan Presiden Nomor 29 Tahun 2014 tentang Sistem Akuntabilitas Kinerja Instansi Pemerintah. 